\title{
Editorial Volume 12
}

\author{
Sabina W. Lautensach ${ }^{1,2,3}$ \\ ${ }^{1}$ Editor-in-Chief of the Journal of Human Security, Librello, Basel, Switzerland \\ 2 Human Security Institute, Canada \\ 3 University of Northern British Columbia, Terrace, BC, V8G 4A2, Canada; E-Mail: salaut@gmail.com
}

Published: 18 February 2016

\section{Dear Reader,}

As I write this, first official reports confirm the existence of gravitational waves which Albert Einstein predicted a century ago. Ground breaking scientific discoveries such as this reaffirms to me the spatial relationships between the universe and human security issues, placing those issues into a new perspective that contrasts with perspectives formed by our everyday lives. Nevertheless, for the majority of humanity, human security in its diverse manifestations remains the most significant consideration in their lives, whereas the nature of gravity is hardly given a thought until such time when some clever technologist uses such a new insight and ends up revolutionising our lives.

During the past months the plight of global refugees has reached dimensions that render its neglect politically and morally imprudent. News commentaries as well as official reports have increasingly adopted the term 'refugees' for all sorts of displaced people regardless of the causes of their displacement. This contravenes the official rhetoric of the UNHCR who heretofore stubbornly reserved the term for political refugees only and effectively ignored environmental causes for displacement. With vast regions of the Middle East having become environmentally uninhabitable, that stance is no longer defensible.

Displaced people are all refugees because they are seeking refuge from threats to their physical wellbeing and bodily integrity. To what extent those dangers are political, social, health-related, economic or environmental makes little difference to the fact that they feel threatened, and being offered refuge usually helps them. In a sense they are all environmental refugees because many (if not all) of those threats ultimately arise from environmental problems such as resource scarcity, adverse climate, extreme weather events and other natural disasters, and crises of public health. Even political persecution and discrimination often arises from underlying basic scarcities, as the example of Ruanda indicated.

Furthermore, the label of 'migrant' seems inadequate to describe those people because it refers merely to what they are engaged in: migration. It does not shed light on their goals. In contrast, the goal of a refugee is rather obvious. Worse, dismissing them as 'economic migrants' obfuscates the causal relationship between economies and ecology, the fact that economic security is embedded and absolutely dependent on the integrity of environmental support structures. Those few 'migrants' who really only seek to improve their income situation from adequate to luxurious are not the ones who make the headlines. In fact, they attract other labels altogether-entrepreneurs, investors, or simply immigrants.

The ongoing crisis in Europe has brought to the forefront the question of who should offer refuge to refugees. 'Western' developed countries have traditionally been the preferred destination by far, despite deep cultural disparities and inadequate provisions for integration. It would make much more sense for a Muslim refugee from, say, Mauritania to apply for refuge in a predominantly Muslim country. So why does he instead trust his life and that of his family to a fragile boat on the Mediterranean to seek refuge in a society that is so very different from his native background? Ignorance is surely only one reason among many. Economic aspirations have always been stated as the prime reason. But the plight of Syrians has underscored 
political conflict and environmental insecurity as drivers. In the absence of adequate coordinating efforts by the UNHCR or other organisations with similar globally recognised authority, the refugees continue to choose their destinations according to dominant rumours and affordable transportation channels.

At the receiving end, European countries are being blamed for not providing enough of what are considered adequate support measures, ranging from humanitarian rescue and aid to the establishment of special economic zones in transit countries such as Libya and Turkey. Within the European camp divisions appear; some Scandinavian countries have begun to forcibly return refugees to their home countries, apparently with no regard as to whether such a home is still in evidence. At the other end of the spectrum, Germany has taken the lead in opening its doors to refugees and organising their settlement, against significant popular opposition exploited by the right wing. The small south German town of 35,000 where my mother in law lives currently accepts 800 refugees every day! For the first time in years, Chancellor Merkel is being openly criticised for her political choices.

Other more culturally compatible potential host countries appear relatively unmoved. As I write this, delegates from Saudi Arabia, Jordan, and other Arab countries are conferring in Munich; but their agenda are still dominated by military security. What are affluent Muslim countries such as Malaysia and Indonesia offering those teeming masses on Syrian and Lybian shores? How many Saudi dollars are finding their way towards organising migration operations and third country resettlement programs? The fact that those questions are so obviously rhetorical highlights the extent that governments have failed to step up, and the paucity of empathy among the leaders of Muslim societies. In a globalised world that freely trades goods, services and people, the ideals of humanitarianism can no longer be relegated to 'Western thinking'. Moreover, empathy for fellow Muslims should be unaffected by that prejudice. Most obviously, it is the UN and its branch in charge of refugees, the UNHCR, that have failed to offer adequate leadership, if only in terms of ideas and propositions. Like it or not, the UN remain the world's most important instrument of global governance, despite all its blind spots and inadequacies. Effective mechanisms for the coordination and implementation of mass migration must come from the UN before any national governments or supranational organisation.

The refugees themselves are faced with the traditional Immigrant's Dilemma-how much integration to aim for, how much of their own cultural heritage to abandon. Elsewhere we have proposed concrete measures how both newcomers and host societies can 'prepare to be offended' [1]. The concept of cultural safety allows for the analysis of challenges and offers prescriptive strategies for minimising sources of insecurity for ethnocultural minorities in disparate host societies. Among the many challenges associated with the situation of resettled refugees and ethnocultural minorities, two prominent issues deserve special attention: violence against women and the public critique of humanitarian action.

In a news item of 28 December 2012, an Italian village priest denounced women for inviting domestic violence by not being subservient enough. In 2013 , one of the young female students who was gang raped on a bus in India died in the Singapore hospital where she had received intensive care. New Year's Eve 2015 in Cologne saw scores of women assaulted by a mob of up to 1,000 young men reportedly of North African and Arab descent, some of them asylum-seekers and undocumented migrants. The public reaction, delayed by an attempt by the media to downplay the events, has divided feminist and anti-racist advocates [2]. At least some of the assaults appeared to have been premeditated and organised. Collective and organised violence against women has assumed new dimensions in peacetime and war [3]. A nasty aggravating feature is the attitude with which victims of rape are treated by their families and communities in some cultures. The underlying cultural values that inform such assaults and the treatment of their victims make it glaringly obvious that not all cultural values are sacrosanct, that some of those values are direct causes of human insecurity and thus no longer defensible by anti-racist arguments. This is a lesson that must be heeded by all would-be immigrants in the interest of human security.

Activists and organisations that try to help newcomers make a home in their new host society are occasionally subjected to public critique labelling them as 'do-gooders'. The term tends to be used by critics to contrast themselves against their opponents. Users of the term imply that they themselves are something other than 'do-gooders', which begs the question what exactly constitutes the antonym. The label is applied to people with active agenda towards altruistic benefits, the 'public good'. They have a clear vision of what agenda and goals the public good entails and openly advocate their underlying values. They follow the principles of vociferous advocacy and the moral duty to take action wherever it promises concrete progress towards those goals. Their strategies are informed by virtues such as non-violence, impartial judgment, and empathic prioritisation of the greatest benefits for those with the greatest need.

The antonym can pertain to the person's convictions and/or to the person's actions. The convictions of persons who regard themselves as 'not do-gooders' are necessarily opposed to the convictions of altruism, public welfare and social justice. That leaves primarily ideals based on selfinterest, partiality, materialism, competition and privilege. These ideals are seldom advocated explicitly; it is much easier for their advocates to merely attack the opponent's convictions. As for actions, the antonym implies either their lack as in confident laissez-faire, circumspect waitand-see, or just fatalistic passivity. These actions can only be sufficiently differentiated from those of the do-gooder if they are directed towards self-enrichment, inequity, social stratification, favouritism, or towards external targets 
to be dominated. Such actions do not exclude violence, victimisation, aggression and the neglect of society's most needy. Again, these are not agenda that are prudent to advertise-hence the focus on disparaging the opponent's instead. Bystanders judging between the two sides would evaluate the values, motives, decisions, and actions. The do-gooder tends to be open about those, although deception under that banner has been known to occur. For the antonym, well, we have yet to find a label. If they really do not share any of the do-gooder's values and motives, and if they disagree wholeheartedly with their decisions and actions, then I can think of only one: a criminal.

In the post-COP21 context humanity has recognised that global environmental change will progressively reduce

\section{References and Notes}

[1] Lautensach AK, Sabina W. Prepare to be Offended Everywhere: How Cultural Safety In Public Places Can Prevent Violent Attacks. International Journal of Sustainable Future for Human Security. 2015;3(1):56-62.

[2] Symons EK. Cologne attacks: This is sexual violence habitable and bioproductive land areas, leading to the eventual displacement of millions. Populations continue to grow. If even only the mid-range estimates of sea level rise become reality, the primary mode of human habitation in this century is likely to be the refugee camp. In the effort to develop effective and just contingencies, we would do well to treat the current challenges regarding refugees as opportunities for rehearsal, for determining which measures work best to ensure a modicum of human security for those unfortunate enough to be deprived of their homes.

Best wishes,

Sabina

directed towards women. The New York Times. 2016 January 19; Available from: http://nytlive.nytimes.com/ womenintheworld/2016/01/19/cologne-attacks-this-issexual-terrorism-directed-towards-women/.

[3] Nutt S. Damned Nations: Greed, Guns, Armies, and Aid. Toronto, Canada: McClelland \& Stewart; 2011. 